\title{
Review on Determinant of Rural Livelihood Strategy and Household Food Security in Ethiopia
}

\author{
Gemechu Beri ${ }^{1}$ and Alemayehu Keba ${ }^{2}$ \\ Ethiopian Institute of Agricultural Research, P.O. Box 2003, Addis Ababa, Ethiopia
}

\begin{abstract}
The livelihood of most people in Ethiopia depends on survival agriculture whose carrying capacity has reduced due to rapid population growth rate and farm size reduction. The main objective of this review is to identify the determinant of rural livelihood strategy and household food security in Ethiopia. Data was collected from different research papers that have to do with the determinant of rural livelihood strategy and household food security in Ethiopia. According to the review result disguised agricultural employment, inadequate access to fertile land, lack of access to farm input, markets, deterioration of natural resource base and incomplete credit among others, wage-earning opportunities, investing in children education, Age of the household head, distance from irrigation sources, social status, soil fertility status, education level, distance from DA office, Economical Active members, soil fertility status, soil conservation and transportation services, saving to invest, and availability of growth engines like private investments were the determinant of rural livelihood strategy and sex, ceremonial expense, dependency ratio, marital, land size, education, livestock and pesticide were the determinant of rural household food security in Ethiopia. In addition to these, the review is forward the concrete recommendation, which implies helping to improve rural household livelihood and household food security through basic policy implication and the participation of the rural household.
\end{abstract}

Keywords: livelihood strategy, food security, Ethiopia

DOI: $10.7176 / \mathrm{JESD} / 12-9-02$

Publication date:May $31^{\text {st }} 2021$

\section{INTRODUCTION}

\subsection{Background of the study}

Agriculture is the main livelihood strategy in developing countries. It absorbs a huge rural labor, generates a significant share of GDP, and is a crucial sector to address food security (Hazel,2010). However, agriculture in sub-Saharan Africa is dependent on a variable climate. In addition to this, farmers in Africa live on a small hectare of farmland. The decimation of farm size accelerates and hence thwarts efforts to increase farm productivity. Therefore, in line with augmenting agricultural productivity, looking for another way out has been put forward as an equally potent strategy for addressing household food security (Stifel, 2010).

Livelihood strategies pursued by rural households are at the heart of examining their food security (IFPR, 2015). Food security is an outcome closely linked to viable livelihood strategies (Matshe, 2009). The majorities of the world's food-insecure are rural smallholder farmers and inhabit the developing world (UNECA 2013; Hazell, 2010). About 23.8 percent of food-insecure people worldwide live in sub-Saharan Africa (SSA) (FAO, WFP, and IFAD 2014). Of this proportion, 80percent live in rural areas, working as peasants, landless laborers, and pastoralists who are often labeled with resource dearth (Rural Poverty Report 2011).

Ethiopia is one of the agrarian countries where 84 percent of its total population lives in rural 90 percent depend mainly on crop production for its livelihood. Smallholder farming dominates its production (CSA 2011). Agriculture contributes $45 \%$ of GDP, more than $80 \%$ of employment opportunities, and over $90 \%$ of the foreign exchange earnings of the country (Yishak et al., 2014; Yenesew et al., 2015). Nonetheless, Ethiopian agriculture is less productive even by the SSA standard. Thus, the nation has a large population of poor and food insecure of which the largest group is rural people with insufficient assets to produce and purchase food (Getahun 2003).

Ethiopian Food Security Strategy identified landless, ox-less, female-headed, elderly, poor on agricultural households, and newly established settlers as food insecure. Their chronic food insecurity is mainly attributed to the low return livelihood system (Masefield 2001). While efforts to ensure adequate food supplies at the national level have done well, these paths on their own fail to ensure food security for households and individuals (MoFED 2012). Policies thus need to promote access to assets and alternative livelihoods (Mesfin 2014).

The severity of rural livelihood and poverty in developing countries like Ethiopia has necessarily informed a drift in her agricultural systems from the strengthening of national research systems towards systems that enable innovations from individuals and communities, proper transfer and utilization of knowledge and overall transformation. Agricultural productivity remained low as a result not only lack of appropriate technologies and lack of access to those technologies, inputs, credit and access to markets and rural infrastructure, but also because of gaps in information and skills that prevented rural producers from effectively utilizing and adopting technologies (Sanginga et al., 2009).

A large portion of the Ethiopian population have been affected by chronic and transitory food insecurity. 
The situation of chronically food insecure people is more and more severe. Food security situation in Ethiopia is highly linked up to severe, recurring food shortage and famine, which is associated with recurrent drought. Currently, there is a growing consensus that food insecurity and poverty problems are closely related in the Ethiopian context. More than $50 \%$ of the total population, of whom the majority reside in rural areas, does not have access to the medically recommended minimum average daily intake of $2100 \mathrm{Cal}$ per person per day (USAID, 2012).

There have been studies conducted on the determinant of rural house hold livelihood strategy and household food security in Ethiopia. In spite of the fact that the Ethiopian government gave special attention to the rural house hold livelihood strategy and food security and tried to establish and support rural house hold to enhance their stability by food security, but in the country are there are no paper published on the determinant of rural house hold livelihood strategy and household food security together for policy maker to simply identify the determinant of rural house hold livelihood strategy and household food security as the whole country.

\subsection{Objectives}

the objective of this review is the determinant of rural livelihood strategy and household food security in Ethiopia.

\section{LITERATURE REVIEW}

\subsection{Theoretical Review \\ 2.1.1. Concept of Livelihood}

There is no universally endorsed definition to grasp the term livelihood (Scoones, 2009). The most widely used definition of livelihood is the one offered by Chambers and Conway built on participatory practices of the World Commission on Environment and Development. A livelihood comprises the capabilities, assets (including both material and social resources) and activities required for a means of living. A livelihood is sustainable when it can cope with and recover from stress and shocks and maintain or enhance its capabilities and assets both now and in the future, while not undermining the natural resource base (Chambers and Conway2009) vital components of this definition are assets, capabilities and activities required for means of living.

Assets are resources that households combine to choose between available options of living for positive outcomes (Krantz 2001). From a livelihood perspective, these resources involve natural, social, financial, human, and physical capitals each having different elements. Following the above definition, Carney (2007), acknowledges the notion of claims and access that enable households to combine their resources at disposal under wider structures and institutions to make a livelihood. For Bebbington (2012), resources not only shape livelihood strategies but also bake capabilities to act and to confront the social conditions that produce poverty. They are also the basis of an agent's power to act and to reproduce, challenge, or change the rules that govern the control, use, and transformation of resources. Capabilities are functions of peoples' initial endowments of different types of capital assets that further strengthen the ability of people to undertake activities for cherished goals (Ellis 2000). For rural households, the ability to produce and feed its members relies on being able to farm or acquire from other sources which in turn depends on the possession of assets like skills, farmland, finance, market, and social networks.

\subsubsection{Concept of Food Security}

Household food security is a relatively new arena in the 1980s, relative to the generic concept of food security. An important shift was seen mid-1990s when the attention was drawn to not only at the international and national levels of food security but also to households and individuals (Paramitta,2013).

The World Food Summit first coined the concept of food security in 1974, defining it as, availability at all times of adequate world food supplies of basic foodstuffs to sustain a steady expansion of food consumption and to offset fluctuations in production and prices. This definition initiated the food availability approach, which dictates food security as a function of production. In other words, food insecurity is a result of product failure; the path out of food insecurity can be accelerated through increasing production. This view coincides with Malthusian assumptions of incommensurable population growth rate and production pace all over the world (Burchi and De Muro, 2012).

FAO (2009) announced the latest definition of food security which reads. Food security is a situation that exists when all people, at all times, have physical, social, and economic access to sufficient, safe, and nutritious food that meets their dietary needs and food preferences for an active and healthy life. This notion downplayed objective measurements of food insecurity (like calorie requirement) due to their definitional ambiguity of what is considered 'enough' for an individual (Paramitta, 2013).

This lacks disaggregation and hence misleads policy intervention (Burchi and De Muro, 2012). For the food entitlement approach, the units of analysis are individuals as well as households (ACF, 2010).

\subsubsection{Livelihood Strategies and Food Security Linkages}

Livelihoods strategies underpin food security (Patel et al., 2015). The most important aspect of livelihood to 
understand while analyzing household food security is how people produce food by themselves, and the means of securing income to buy food from other sources (Chikopela ,2014). Strategies may lead to more or less satisfactory livelihood outcomes. Food insecurity is the result of unsatisfactory livelihood strategies (Løvendal, Knowles and Horii 2004; ACF, 2010).

Food production constitutes one of the critical livelihood activities and an indispensable source of food access for rural households (Matse, 2009).

The problem, however, is that the poorest do not have resources either to grow an adequate quantity of food or to purchase it from the market. Their coping strategies are considerably minimal (FAO, WFP, and IFAD 2012). Matshe (2009) pinpointed that understanding of the structural predicaments sustaining food insecurity in African rural areas found their base in local livelihood strategies.

\subsubsection{Measuring Food Security Outcome}

Attributed to its multidimensional and multicomponent nature, food security remains a tricky concept to measure. As a result, suites of indicators were proposed and adopted over time with indifferent contexts (Ballard, Kepple and Cafiero 2013). Experience-based household food security measurement (Coates, Swindale and Bilinisky 2007), and anthropometry are among the dominant measures of food security.

Hence, households' dietary level is measured against objectively set threshold measurements. It involves converting household food consumption into calories and averaging out the household-level. FAO's (2010) populations' average energy requirement of 2200 kilocalorie/capita/day obeys this measurement (Walton, 2012).

HFIAS is drawn on the subjective of households. Household food insecurity (access) is measured using validated Household Food Insecurity Access Scale Version (Coates, Swindale and Bilinsky 2007). HFIAS incorporates three fundamental components: uncertainty and anxiety over food, perceptions that food is of insufficient quantity and quality, and reported reduction of food intake due to lack of resources (Swindale and Bilinisky, 2006).

\subsection{Determinants of Rural Livelihood Strategies}

The determinants of rural livelihood strategies reveal different factors as predictors of livelihood strategy choices. Nonetheless, common among this review is its focus on assets, institutions, and contexts (Rahut et al., 2012. Synthesizing the findings of different investigations, (Obi 2011) identified variables influencing livelihood strategy choices into individual characteristics, household characteristics, and community characteristics.

The former results from disguised agricultural employment, inadequate access to fertile land, lack of access to farm input, markets, deterioration of natural resource base, and incomplete credit among others (Obi 2011). Choice reasons for diversifying involve taking advantage of seasonal wage-earning opportunities, investing in children education, saving to invest, and availability of growth engines like private investments (Stifel, 2010; Loison, 2015).

The education level of the household head was found to be one of the most important determinants of livelihood diversification as prior expectation (Gebru et al., (2018); Eshetu et al., (2016).

According to the study of Yuya and Daba (2018). Age of the household head, distance from irrigation sources, social status, soil fertility status, education level, distance from DA office, Economical Active members, soil fertility status, soil conservation and transportation services used were statistically significant variables that determining rural household's choice of livelihood strategies in the study area

\section{3. determinants of rural household food security}

According to Tsegamariam et al.,(2019) study result from the sex, ceremonial expense, dependency ratio, signs are expected to be positive; because they have a direct relationship with food insecurity but the signs of marital, land size, education, livestock and pesticide use are expected to be negative signs, because they have inverse relationship with food insecurity and they affect it adversely. But marital status, education, land size, and sex are insignificance.

Maintaining livestock production was found an important livelihood activity for the majority of the sample households. The increased livestock decrease the predicted probability of the household being food insecure [BARDWW (2017); Kinfe Abraham (2015); Tsegamariam et al., (2019)].

As education increases, labor productivity increases which intern decreases the probability of being food insecure. This is in line with the economic theory which predicts that household asset accumulation increases as years of schooling increases (Eshetu, 2020).

As land size increases, the probability of being food insecure decreases (Eshetu, 2020).

Large family size or dependency ratio reduces the capacity of households to provide sufficient quantity and quality of food to all its members, to care for them when they fall ill and to ensure a good education for children. Studies conducted (Eshetu, 2020). 


\section{CONCLUSION AND RECOMMENDATION}

\subsection{Conclusion}

Rural livelihoods are varied. Households secure their food access based on the activity they undertake. Though the majority of them get food through their production. This indicates that the food production of households is not adequate to feed them. Agrarian households, who are the producers of food themselves, face food shortages.

Therefore, it can be concluded that household level choice of livelihood strategies are crucial in increasing the households' food security status and reducing deficiency levels of farmers which in turn could affect the welfare of the rural farm households.

\subsection{Recommendation}

Rural livelihoods are increasingly diversified. Hence, forward and backward linkages between rural livelihood strategy and food security are needed to be sensitized.

The food security situation of households with different livelihood strategies was found to be different. The possibilities and challenges of different livelihood groups concerning ensuring household food security also differ. So, rural development plans need to consider the heterogeneous nature of livelihood groups to challenges. For rural livelihood to thrive, resource-mobilizing associations are needed. This would have gains of enhancing human capital in addition to improving the economic performance of households.

\section{REFERENCES}

ACF.2010. Food Security and Livelihood Assessments: A Practical Guide for Field Workers Technical Department of Food Security and Livelihoods.

Ballard, T.J., Anne W. Kepple and Carlo Cafiero .2013. The food insecurity experience scale:Development of a global standard for monitoring hunger worldwide.

BARDWW (Bureaus of Agricultural Rural Development of Woliso Woreda, 2017) Woliso, Ethiopia. Kinfe Abraham (2015) Strategic Response to Food Security, Ethiopian dynamic economic reform, 1st edn, AdissAbeba Ethiopia.

Bebbington, A.2012. Capitals and capabilities: A framework for analyzing peasant viability, ruralLivelihoods and poverty in the Andes. Institute for Environment and Development, London:UK.

Burchi and Muro 2012: Burchi, F. \& De Muro, P. 2012. A Human Development and Capability Approach to Food Security: Conceptual Framework and Informational Basis. Working Paper 2012-009: United Nations Development Programme.

Chambers, R and Gordon Conway (2009), Sustainable Rural Livelihoods: Practical Concepts for The 21st Century. IDS Discussion Paper No. 296; Brighton: Institute of Development Studies.UK.

Coates,J., Anne Swindale and Paula Bilinisky. 2007. Household Food Insecurity Access Scale (HFIAS) for Measurement of Food Access: Indicator Guide, VERSION 3. Washington, DC:Food and Nutrition Technical Assistance Project (FANTA).

CSA.2011. Agricultural Sample Surveys. Central Statistical Agency, Addis Ababa, Ethiopia.

Ellis, F. 2000. Rural Livelihood and Diversity in Developing Countries. Oxford: OxfordUniversity Press.

Eshetu F, Mekonnen E. Determinants of of farm income diversifcation and its efect on rural household poverty in Gamo Gofa Zone, Southern Ethiopia. J Dev Agric Econ. 2016;8(10):215 27.

Eshetu, F., 2020. Determinants of Rural Households Food Insecurity in Southern Ethiopia. Asian Food Science Journal, pp.29-43.

FAO, WFP and IFAD. 2014. The State of Food Insecurity in the World 2014: Strengthening the Enabling environment for food security and nutrition. Rome: FAO.

FAO. 2010. "Country profile: Food security indicators: Ethiopia." Retrieved December, 2015 (http://www.fao.org/fileadmin/templates/ess/documents/food_security_statistics/country_profi

FA0.2009. Declaration of the World Summit on Food Security. World Food Summit 16-18 November 2009. Rome

Gebru, G.W., Ichoku, H.E. and Phil-Eze, P.O., 2018. Determinants of livelihood diversification strategies in Eastern Tigray Region of Ethiopia. Agriculture \& Food Security, 7(1), p.62.

Getahun Bikora. 2003. Food security Challenges in Ethiopia: proceedings of the food security Conference. Professional Associations Joint Secretariat. Addis Ababa, Ethiopia.

Hazell, P., 2010. "The rural non-farm economy: Prospects for Growth and poverty reduction." World Development 38(10):1429-1441.

Krantz, L. 2001. A sustainable livelihood approach to poverty alleviation. SIDA.les/eng/Ethiopia_E.pdf).

Loison, S.A. 2015. "Rural Livelihood Diversification In Sub-Saharan Africa: A literature review." The Journal of Development Studies 51(9): 1125-1138.

Løvendal, C.R., Marco Knowles and Naoko Horii. 2004. Understanding Vulnerability to Food Insecurity Lessons from Vulnerable Livelihood Profiling. ESA Working Paper No. 04-1 8. Agricultural and 
Development Economics Division (ESA). Rome: Food and Agriculture Organization.

Matshe, I.2009. "Boosting smallholder production for food security: some approaches and Evidence from studies in sub-Saharan Africa”. Agrekon 48 (4): 483-511.

Mesfin Welderufael. 2014. "Determinants of Households Vulnerability to Food Insecurity in Ethiopia: Econometric analysis of Rural and Urban Households." Journal of Economics and Sustainable Development 5(24):70-79.

MoFED (Ministry of Finance and Economic Development). 2012. Ethiopia's Progress Towards Eradicating Poverty: An Interim Report on Poverty Analysis Study (2010/11). Addis Ababa,Ethiopia.

Paramitta, P. 2013. "Between Chamkar and the Kitchen: A Livelihood Approach to The Implication Of Land Grabs On Food Security In Cambodian Rural Households.” MA thesis, Graduate Institute of International and Development Studies, Geneva.

Rahut, B and M. Micevska Scharf. 2012. "Livelihood diversification strategies in The Himalayas." The Australian Journal of Agricultural and Resource Economics 56(1):.558-582.

Sanginga, P. C., Waters-Bayers, A., Kaaria, S., Njuki, J. and Wettasinha, C. (2009) "Innovation Africa: Beyond Rhetoric to Praxis", In: Sanginga, P. C., Waters-Bayers, A., Kaaria, S., Njuki, J., and Wettasinha, C. (eds.) "Innovation Africa: Enriching farmers livelihoods", Earthscan: London, pp. 374-386.

Scoones, I.2009. Sustainable livelihoods, a framework for analysis, IDS Working Paper Number 72, Brighton: Institute of Development Studies.

Stifel, D.2010. "The rural non-farm economy, livelihood strategies and household Welfare." African Journal of Agricultural Research 4 (1): 82-109.

Technical Paper. FAO. Rome. Retrieved January 2016 ( http://www.fao.org/economic/ess/ess-fs/voices/en/).

Tsegamariam Dula, Wakjira Berhanu. Determinants of Rural Household Food Security and Coping Up Mechanisms in the Case of Woliso Woreda Western Ethiopial. World J Agri \& Soil Sci. 1(2): 2019. WJASS.MS.ID.000507. P

UNECA. 2013. Assessing Progress in Africa towards the Millennium Development Goals: Food Security in Africa: Issues, challenges and lessons. The United Nations Economic Commission For Africa (ECA).

Walton. G. 2012. "Sustainable Livelihoods and Food and Nutrition Security of Kenyan Smallholder Farm Women." PhD Dissertation, Department of Health Management, University of Prince Edward Island. Canada.

Yenesew Sewnet, Yizengaw, Eric Ndemo Okoyo, and Fekadu Beyene .2015. "Determinants of Livelihood diversification strategies: The case of smallholder rural farm households in Debre Elias Woreda, East Gojjam Zone, Ethiopia." African Journal of Agricultural Research 10(19):1998-2013.

Yishak Gecho, Gezahegn Ayele, Tesfaye Lemma, and Dawit Alemu. 2014. "Rural household Livelihood strategies: Options and determinants in the case of Wolaita Zone, Southern Ethiopia." Social sciences 3(3): 92-104.

Yuya, B.A. and Daba, N.A., 2018. Rural Households Livelihood Strategies and its Impact on Livelihood Outcomes: The Case of Eastern Oromia, Ethiopia. AGRIS on-line Papers in Economics and Informatics, 10(665-2018-3629), pp.93-103. 